\title{
Lead-Induced Damage on Hepatocytes and Hepatic Reticular Fibres in Rats; Protective Role of Aqueous Extract of Moringa oleifera Leaves (Lam)
}

\author{
Bukola R. Omotoso' ${ }^{1}$ Adeleke A. Abiodun ${ }^{1 *}$, Omamuyovwi M. Ijomone ${ }^{1,2}$, \\ Stephen 0. Adewole ${ }^{1}$ \\ ${ }^{1}$ Department of Anatomy and Cell Biology, Obafemi Awolowo University, Ile-Ife, Nigeria \\ ${ }^{2}$ Department of Human Anatomy, Cross River University of Technology, Okuku Campus, Nigeria \\ Email: aaabiodun76@yahoo.com
}

Received 4 April 2015; accepted 10 May 2015; published 15 May 2015

Copyright (C) 2015 by authors and Scientific Research Publishing Inc.

This work is licensed under the Creative Commons Attribution International License (CC BY).

http://creativecommons.org/licenses/by/4.0/

\section{(c) (i) Open Access}

\section{Abstract}

This study was designed to evaluate the hepatoprotective and ameliorative effects of aqueous extract of Moringa oleifera (MO) leaves on the histologyof liver and hepatic reticular fibres integrity of adult Wistar rats following lead-induced hepatotoxicity. Twenty four adult Wistar rats, weighing 180 - $220 \mathrm{~g}$, randomly assigned into four groups of six animals each were used for the study. Lead and Moringa oleifera were given orally to the rats. 24 hours after the last administration, animals were sacrificed, blood obtained by cardiac puncture and liver excised, fixed in $10 \%$ phosphate buffered formalin for histological and histochemical analysis. The activities of aspartate amino transferase (AST), alanine amino transferase (ALT) and alkaline phosphatase (ALP) were used as markers of hepatotoxicity and catalase (CAT) activity were used as marker to evaluate the anti-oxidant status of the tissue. Result showed that lead treatment increased markers of hepatic damage (ALT, AST and ALP) and decreased CAT activities. Histological studies reveal alterations of hepatic structure including hepatocytic vacuolations, sinuosoidal congestion and loss of reticular fibres following lead treatment. Treatment with MO prevented and reversed lead induced hepatic damage. In conclusion, this study shows that Moringa oleifera leaf extract has an appreciable ability to prevent hepatotoxicity caused by lead, partly as result of its chemical constituents which has hepatoprotective properties.

\section{Keywords}

Lead, Moringa oleifera, Liver, Reticular Fibres, Rats

\footnotetext{
${ }^{*}$ Corresponding author.
}

How to cite this paper: Omotoso, B.R., Abiodun, A.A., Ijomone, O.M. and Adewole, S.O. (2015) Lead-Induced Damage on Hepatocytes and Hepatic Reticular Fibres in Rats; Protective Role of Aqueous Extract of Moringa oleifera Leaves (Lam). Journal of Biosciences and Medicines, 3, 27-35. http://dx.doi.org/10.4236/jbm.2015.35004 


\section{Introduction}

Health problems caused by toxic environmental compounds are becoming a global challenge. Increase urbanization and ensuing industrialization may contribute to continuous human exposure to many toxic environmental pollutants. Lead is considered as one of the major environmental pollutants and is amongst four metals that have the most detrimental effects on human wellbeing; the other being cadmium, mercury and arsenic [1]. It is very soft, vastly pliable, ductile, and a reasonably poor conductor of electricity [2]. Lead has been used widely since 5000 BC for application in metal products, pipelines, cables, as well as in paints and pesticides [3]. This abundant ecological pollutant enters the atmosphere via fabrication of coal, oil, iron, batteries, and steel, and also from smelters, refuge, and tobacco smoke. It can enter the human body via uptake of food (65\%), water (20\%) and air (15\%) [4]. Lead interferes with bio-systems by alterations in their molecular interactions, signalling processes, and ultimately cellular function. Lead toxicity is well-known in mammals, leading to a wide-ranging biochemical, physiological, and behavioural dysfunctions [5]. Research on the toxic effects of lead continues and in the last decade new information suggests manifold influences of this metal on human health.

The liver is one organ that is seen to be susceptible to heavy metal toxicity, including lead [6] [7]. The liver is a vital organ with a wide range of functions such as detoxification, protein synthesis and production of biochemical necessary for digestion. It is actively involved in many metabolic functions and is the frequent target for a number of toxicants [8]. Hepatic damage is associated with distortion of metabolic functions which include detoxification, protein synthesis, and digestive functions [9]. In the absence of consistent hepatoprotective drugs in allopathic medicine, herbs demonstrate therapeutic functions in treatment of several liver damage and disorders [10]. Hence, searching for safe and potent remedies from the herbal origin for the treatment of hepatic disorder has become the most fascinating and desired area of research [11].

Moringa oleifera (MO) is a multipurpose tree widely distributed in India, the Philippines, Sri Lanka, Thailand, Malaysia, Burma, Pakistan, Singapore, The West Indies, Cuba, Jamaica and Nigeria [12]. All the parts have been reportedly engaged singly or with other plants for treating diverse illnesses and diseases [13]-[15]. Leaves of this plant are traditionally known for their several biological actions, including lowering cholesterol levels [16], regulation of thyroid hormone status [17], anti-diabetic agent [18], anti-tumor agent [19] and anti-hypertensive agent [20].

The present study evaluated microstructural changes following simultaneous administration and post-administration of aqueous MO extract on lead-induced toxicity in liver of rats. The study also evaluated changes in catalase as a marker for oxidative stress in liver, as well as changes in biomarkers of liver damage.

\section{Materials and Method}

\subsection{Animal Care and Management}

Twenty four healthy male adult Wistar rats weighing 180 - 220 g were obtained from the Animal House, Faculty of Basic Medical Sciences, Obafemi Awolowo University (OAU). Animals were maintained on standard lab pellet diet and tap water ad libitum. They were housed in clean plastic cages with wood chip bedding, under natural day/light cycle, at ambient temperature. Rats were acclimatized for 2 weeks prior to experimental regimen. All animals were handled in accordance with guidelines for animal research as detailed in the NIH Guidelines for the Care and Use of Laboratory Animals (NIH Publication 2011) and experimental protocol were approved by local institutional research ethics committee.

\subsection{Extraction of Plant Material}

Fresh Moringa oleifera (MO) leaves were plucked from the lawn of Chemical Engineering Department, OAU, identified and authenticated by taxonomist at the Department of Botany, OAU. MO leaves were air dried at room temperature for weeks, weighed every three days to ascertain dryness by having the same weight. The air-dried leaves were ground into fine powder with an electronic pulverizing machine (Daiki, DIK-2910, Tokyo, Japan). The powdered leaf (500 g) was extracted with $2 \mathrm{~L}$ distilled water for 24 hours. The mixture was filtered using Whatman filter paper (No. 1) and the filtrates were allowed to evaporate at $50^{\circ} \mathrm{C}$ using a vacuum rotary evaporator [21]. The wet residue was freeze-dried using a vacuum freeze drier and stored in a desiccator. An aliquot portion of the crude extract residue was dissolved in distilled water for use on each day of the experiment. 


\subsection{Experimental Design}

The rats were randomly assigned into 4 groups of 6 rats each (Groups A, B, C, and D). Animals were treated as follows;

Group A (Normal Control): Control, rats were given normal feed and distilled water only.

Group B (Lead $(\mathrm{Pb})$ only) rats were administered with $50 \mathrm{mg} / \mathrm{kg}$ body weight of lead nitrate only for 14 days.

Group C ( $\mathrm{Pb} \& \mathrm{MO}$ ) rats were administered with $50 \mathrm{mg} / \mathrm{kg}$ body weight of lead nitrate and $500 \mathrm{mg} / \mathrm{kg}$ body weight of Moringa oleifera aqeous extract simultaneously for 14 days.

Group $\mathrm{D}(\mathrm{Pb}+\mathrm{MO})$ rats were administered with $50 \mathrm{mg} / \mathrm{kg}$ body weight of lead nitrate for 14 days and 500 $\mathrm{mg} / \mathrm{kg}$ Moringa oleifera aqeous extract for another 14 days.

Lead nitrate was dissolved in distilled water before use. Lead and MO extract were administered by oral galvage. Twenty-four hours after the last administration, the animals were sacrificed by cervical dislocation. Through a midline incision on the anterior abdominal wall, the heart was accessed and blood sample were collected by cardiac puncture. These were stored in $5 \mathrm{ml}$ plain bottle for biochemical evaluation. The liver was quickly excised, and its absolute weight obtained using a top loader sensitive balance (Mettler Toledo Germany), and immediately fixed in $10 \%$ phosphate buffered formalin for 24 hours for subsequent histological and histochemical analysis. Lead nitrate was obtained from Sigma Chemicals, USA, and all other chemicals were of analytical grade.

\subsection{Biochemical Analysis}

Blood sample were centrifuged at $5000 \mathrm{rpm}$ for 15 minutes to obtained serum with a bench centrifuge (Ma-Donax, England). Serum obtained was used to estimate markers of hepatic damage; aspartate amino transferase (AST), alanine amino transferase (ALT), and alkaline phosphatase (ALP). These were estimated using colorimetric assay kits (Randox Laboratories, UK).

Catalase (CAT) activity, a marker for oxidative stress, determined according to the method of Sinha (1972) [22]. This method is based on the fact that dichromate in acetic acid is reduced to chromic acetate upon heating in the presence of $\mathrm{H}_{2} \mathrm{O}_{2}$, and perchromic acid is formed as an unsteady intermediate. The chromic acetate then produced is measured calorimetrically at $570-610 \mathrm{~nm}$. Since dichromate has no absorbency in this region, the presence of the compound in the assay mixture does not interfere at all with the colorimetric determination of chromic acetate. The catalase preparation is allowed to split $\mathrm{H}_{2} \mathrm{O}_{2}$ for different periods of time. The reaction is stopped at a particular time by the addition of dichromate/acetic acid mixture and the remaining $\mathrm{H}_{2} \mathrm{O}_{2}$ is determined by measuring chromic acetate calorimetrically after heating the reaction mixture.

\subsection{Histological and Histochemical Studies}

Fixed tissues were processed for paraffin wax embedding. Sections were cut on a rotary microtome at $5 \mu \mathrm{m}$ thickness. Sections were stained with routine haematoxylin and eosin (H \& E) for general histology, Gordon and Sweet staining for reticular fibres, and Periodic-Acid Schiff staining for glycogen deposits as described in Drury and Wallington (1980) [23].

\subsection{Statistical Analysis}

Data were expressed as mean \pm SEM. All groups were compared by analysis of variance (ANOVA), followed by Student Newman-Keuls (SNK) test for multiple comparisons. Significant difference was set at $\mathrm{p}<0.05$. GraphPad Prism 5 (Version 5.03, Graphpad Inc.) was the statistical package used for data analysis.

\section{Results}

\subsection{Activities of Markers of Hepatic Damage}

Result show that ALT activities is significantly increase $(\mathrm{p}<0.001)$ following $\mathrm{Pb}$ only treatment. MO treated groups, both simultaneously $(\mathrm{Pb} \& \mathrm{MO})$ and after lead treatment $(\mathrm{Pb}+\mathrm{MO})$ showed significant attenuation of this effect. However, $\mathrm{Pb} \& \mathrm{MO}$ group was significantly higher than control, while no significant difference in observed between $\mathrm{Pb}+\mathrm{MO}$ group and control (Figure 1). AST activities is also significantly increase ( $\mathrm{p}<$ 0.001) following $\mathrm{Pb}$ only treatment. Also, $\mathrm{MO}$ treated groups, both simultaneously ( $\mathrm{Pb} \& \mathrm{MO}$ ) and after lead 
treatment $(\mathrm{Pb}+\mathrm{MO})$ exhibited significant weakening of this effect. $\mathrm{Pb} \& \mathrm{MO}$ group was significantly higher than both control and $\mathrm{Pb}+\mathrm{MO}$ group. No significant difference is observed between $\mathrm{Pb}+\mathrm{MO}$ group and control (Figure 1). Furthermore, ALP activities is significantly increased $(\mathrm{p}<0.01)$ following $\mathrm{Pb}$ only treatment. Only $\mathrm{Pb}+\mathrm{MO}$ group exhibited significant attenuation this effect. $\mathrm{Pb} \& \mathrm{MO}$ group was significantly higher than both control and $\mathrm{Pb}+\mathrm{MO}$ group. No significant difference is observed between $\mathrm{Pb}+\mathrm{MO}$ group and control (Figure 1).

\subsection{Activities of Catalase}

CAT was significantly reduced $(\mathrm{p}<0.01)$ in $\mathrm{Pb}$ only group compared to control. $\mathrm{Pb} \& \mathrm{MO}$ groups showed significant amelioration of reduced CAT activities. $\mathrm{Pb} \& \mathrm{MO}$ group showed significantly higher CAT activities compared to $\mathrm{Pb}+\mathrm{MO}$ and no significant difference compared to control. Contrastingly, $\mathrm{Pb}+\mathrm{MO}$ did not show any significant improvement in reduced CAT activities (Figure 2).

\subsection{Liver Histological and Histochemical Assessment}

Liver of control rats presents normal histological profiles with intact hepatocytes and hepatic sinusoids between them. $\mathrm{Pb}$ only rats show disruption of the normal structural organization of the hepatic lobules and loss of the characteristic cordlike arrangement of the normal liver cells. Hepatocytes appear mostly hyperchromatic with occasional vacuolations. Also, sinusoids appear congested. Simultaneous treatment of lead and MO produced improvement in liver histology, though occasional sinusoidal congestions are observed. MO treatment for 14 days following lead exposure exhibited a remarkable preservation in their histological profiles comparable to the control animals (Figure 3).
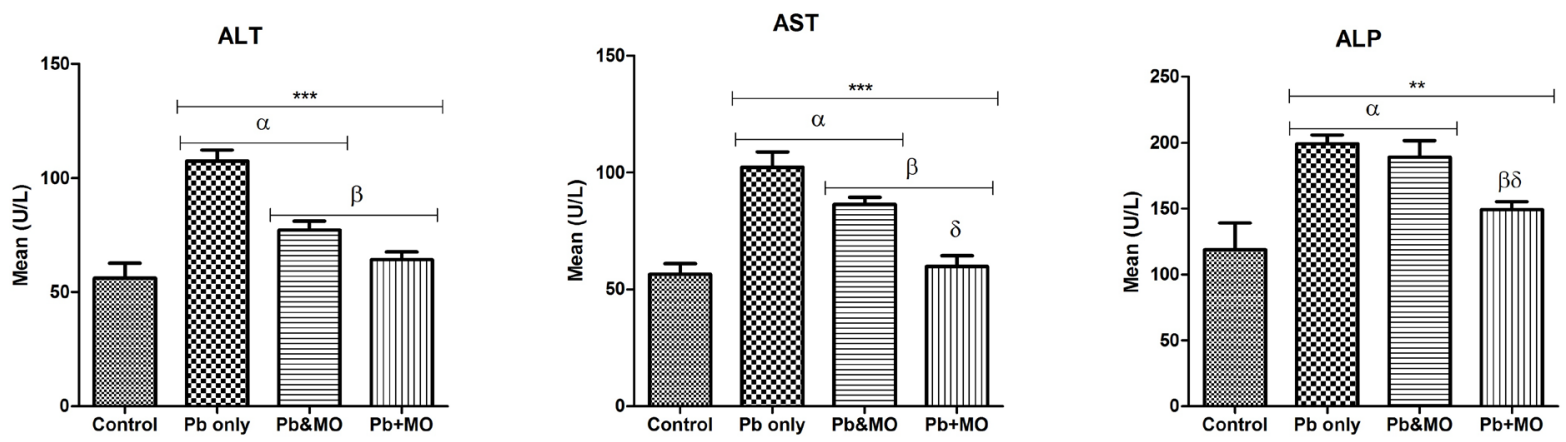

Figure 1. Effects of $\mathrm{Pb}$ and $\mathrm{MO}$ treatment on serum markers of hepatic damage. Bars are mean $\pm \mathrm{SEM}$. ${ }^{* *} \mathrm{p}<0.01$, $* * * \mathrm{p}<$ 0.001. $\alpha, \beta$, and $\delta$ significant difference compared to control, $\mathrm{Pb}$ only and between $\mathrm{Pb} \& \mathrm{MO}$ and $\mathrm{Pb}+\mathrm{MO}$ respectively. One way ANOVA followed SNK.

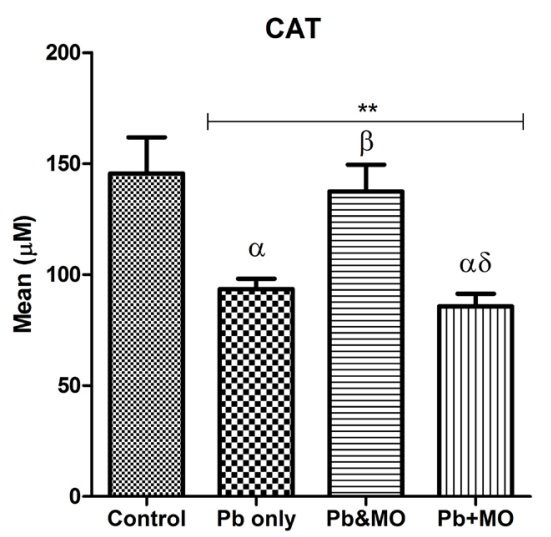

Figure 2. Effects of $\mathrm{Pb}$ and $\mathrm{MO}$ treatment on serum CAT activity. Bars are mean $\pm \mathrm{SEM}$. ${ }^{* *} \mathrm{p}<0.01 . \alpha, \beta$, and $\delta$ significant difference compared to control, $\mathrm{Pb}$ only and between $\mathrm{Pb} \& \mathrm{MO}$ and $\mathrm{Pb}+\mathrm{MO}$ respectively. One way ANOVA followed SNK. 
Silver impregnation method showed conspicuous darkly stained reticular fibres in control and $\mathrm{Pb}+\mathrm{MO}$ rats. The fibres are also well observed in $\mathrm{Pb} \& \mathrm{MO}$ rats, albeit slightly reduced. On the other hand, $\mathrm{Pb}$ only rats exhibited sparse and poorly stained reticular fibres (Figure 4). PAS demonstration of glycogen deposits show moderate staining in all groups (Figure 5).

\section{Discussion}

Exposure to environmental levels of lead $(\mathrm{Pb})$ is a public health problem of global proportion because lead is a
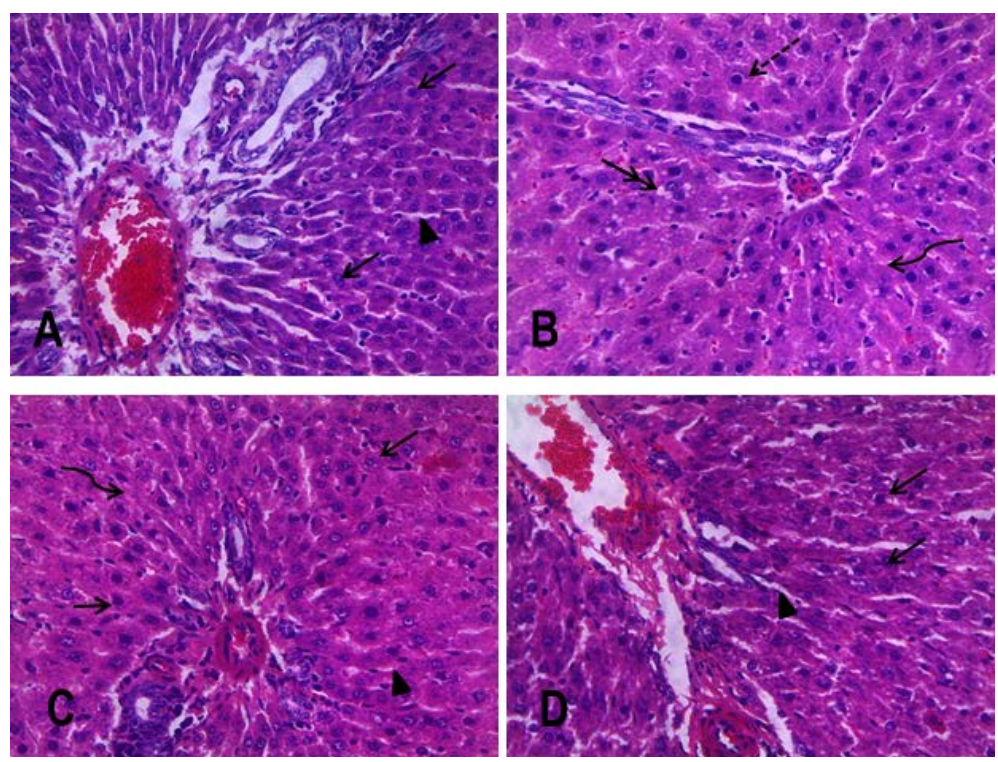

Figure 3. Micrographs of the liver of experimental rats. $\mathrm{H} \& \mathrm{E} \times 400$. Control (A), $\mathrm{Pb}$ only (B), $\mathrm{Pb} \& \mathrm{MO}(\mathrm{C}), \mathrm{Pb}+\mathrm{MO}$ (D). Hepatocytes (arrows); Sinusoids (arrowheads). Observe hyperchromatic nucleus (dashed arrows) and hepatocytic vacuolations in $\mathrm{Pb}$ only. Also observe congested sinusoids (curvedarrows) in $\mathrm{Pb}$ only and $\mathrm{Pb} \& \mathrm{C}$.
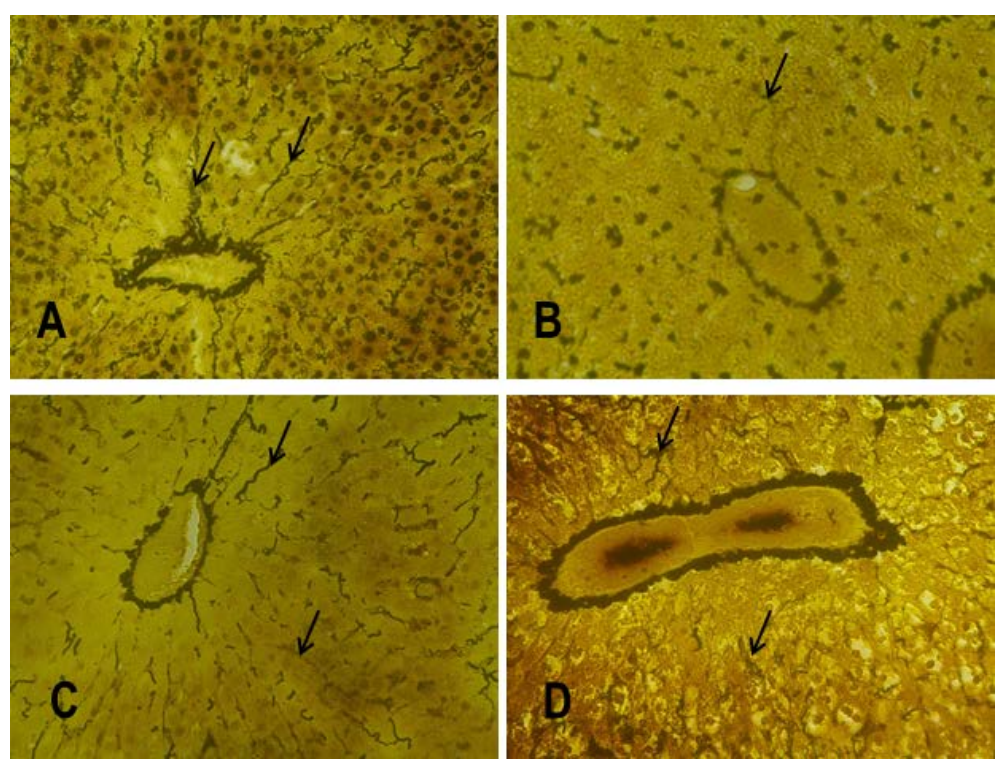

Figure 4. Micrographs of the liver of experimental rats. Gordon and Sweet $\times 400$. Control (A), Pb only (B), Pb \& MO (C), Pb + MO (D). Observe dark stained reticular fibres (arrows), which are sparse and poorly stained in $\mathrm{Pb}$ only. 

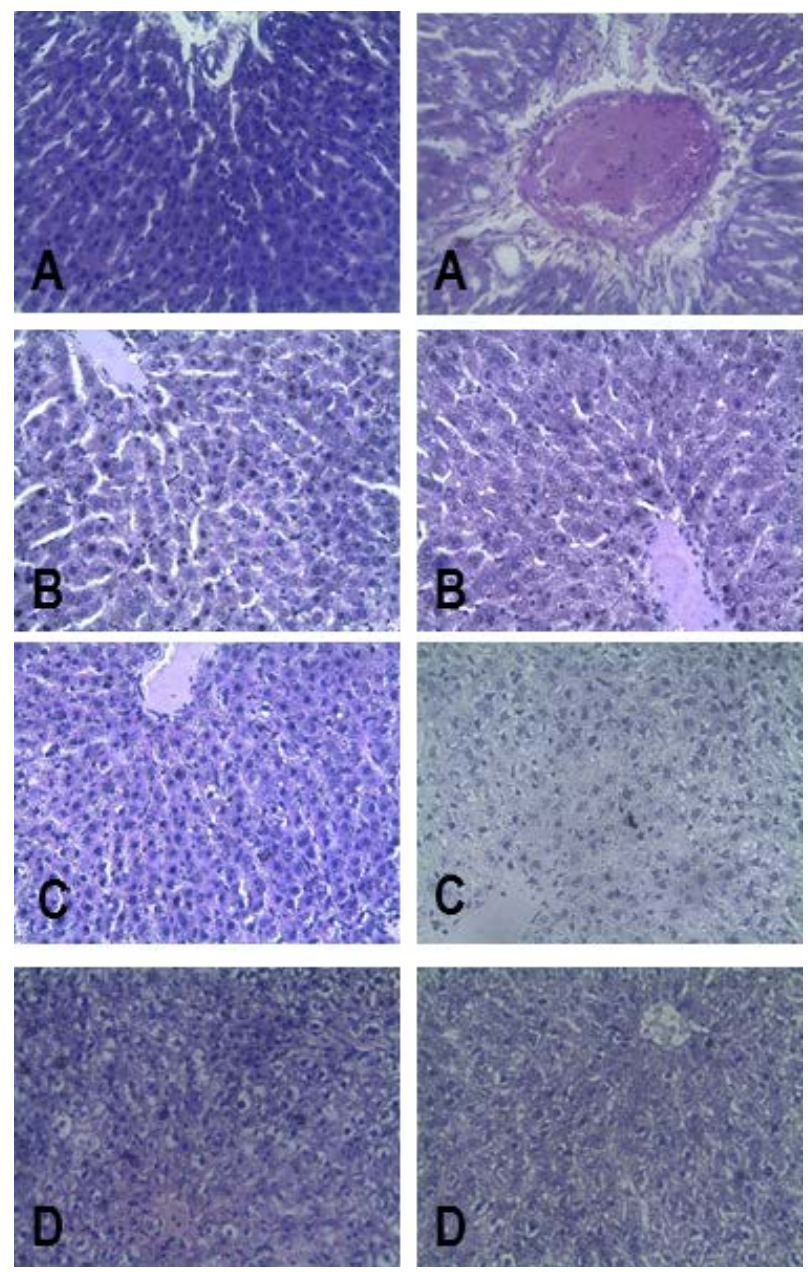

Figure 5. Micrographs of the liver of experimental rats. PAS $\times 400$ (left), PAS-Diastase $\times 400$ (right). Control (A), Pb only (B), $\mathrm{Pb} \& \mathrm{MO}(\mathrm{C}), \mathrm{Pb}+\mathrm{MO}(\mathrm{D})$. Observe moderate PAS staining in all groups.

known toxic metal widely distributed in the environment. The better knowledge of its toxicity is the most outstanding example of how research can impact public health [24], but it continues to be a major public health concern [25].

Exposure of rats to heavy metals such as lead has adverse effects on hepatic cells because after lead exposure, liver is one of the major organs involved in the storage, biotransformation and detoxification [7]. Lead induces a wide range of biochemical and structural alterations to hepatic cells, this is indicative of liver toxicity [6].

The present study showed that serum level of ALT, AST and ALP significantly increased in lead $(\mathrm{Pb})$ only treated group when compared with the control rats and other treated groups. This is an indication of impaired liver function. Increased liver enzyme activity may reflect hepatocyte or biliary epithelial necrosis, compromise of hepatocyte membrane integrity, and cholestasis [26]. Damaged of the membrane of hepatocytes possibly due to lead induced hepatotoxicity releases the enzymes into circulation causing a rise of these enzymes in the blood. Also, the cell membrane is the main target of the oxidative damage formed by xenobiotics, including heavy metals [27]. Lead is known to produce oxidative injury by increasing peroxidation of membrane lipids [28]. This is in accordance with previous findings of [29] [30] which reported lead exposure increases the activity of liver enzyme (ALT, AST and ALP). MO has ameliorative effects on lead-induced liver damage as revealed by reduced serum concentration of AST, ALT and ALP, in MO treated groups. The reversal of elevated serum enzyme levels by MO leaf extract after lead administration may be attributed to the stabilizing ability of the MO on cell membrane, thus preventing enzymes leakages [31]. This is in accordance with the finding of Saalu et al., 
2012 who reported that MO leaf extract have beneficial effect in protecting animal models against alcohol-induced liver oxidative damage [31]

The present study shows that lead treatment caused a significant $(\mathrm{P}<0.01)$ decrease in catalase activities which are in conformity with Sharma et al., 2010 who reported activities of catalase were reduced by lead nitrate thus resulting in peroxidative damage [30]. Cellular systems are sheltered from cell damages caused by reactive oxygen species (ROS) by various defences consisting of antioxidants with diverse functionalities [32]. When the ROS present in the cellular system subdue these defence systems, oxidative stress is induced, and this could result in cellular injuries and ultimately development of diseases. Lead toxicity has shown to form free radical damage by two distinct pathways: 1 ) the production of ROS, inclusive of singlet oxygen, and hydrogen peroxide and 2) the direct reduction of antioxidant reserves. Concomitant administration of MO leaf extract with lead afford significant increase in catalase activity suggesting that MO prevents permeation of the toxins by contending for the same receptor sites on cell membranes. This is possibly due to a blend of two focal mechanisms; 1 ) an modification of cell membranes, such that only slight quantities of toxins may infiltrate into the cell; 2) speeding up of protein synthesis, thus exciting cellular regeneration [10]. This is in contrast with Patra et al., (2001) who reported that lead exposure is associated with significant increases in lipid peroxide level in the liver and brain, whereas changes in the superoxide dismutase and catalase activities in lead-exposed rats did not reach statistical significance [33]

In the present study, histological analysis following lead exposure suggests inflammation of the hepatocyte, hepatocytic vacuolation and congested sinusoids. However, MO extracts treated group shows fewer areas of congestion, wider sinusoidal spaces and presence of binucleated cells indicating proliferation and regeneration which are in conformity with previous study [10] which reported hepatoprotective effect of ethanolic extract of Moringa oleifera against paracetamol induced liver damage in rats. Reticular fibres provide most of the supporting connective tissue of the liver [34]. They line the sinusoids, surrounding the individual sheets of liver cells (hepatocytes) forming the only fibrous connective tissue components supporting the cells [35]. In addition to providing support, reticular fibres also facilitate the interchange of substances between the hepatocytes and the blood, which flows in the irregularly shaped blood vessels (sinusoids) between the hepatocytes [35]. The present study shows that lead exposure causes degeneration of reticular fibres especially around and in the wall of the central vein, which run in full agreement with previous studies that lead is a very toxic agent which affects many vital organs, such as the liver [30] [36]. However, the reticular fibres were restored in MO treated group. Congestion of sinusoids could be as a result of degenerated reticular fibres as shown in the silver impregnation because of their function. Another study also reported that treatment with lead acetate showed severe hepatocytes damage, which was manifested by marked fat vacuolations or empty space, where the portal veins were markedly dilated and congested with blood [37]. The presence of multiple round vacuoles (hepatocytic vacuolation) which indicate lipid accumulation is also supported by ultrastructural study undertaken on the hepatic tissue of male albino mice by [38]. The accumulation of fat droplets in the cytoplasm of the affected hepatocytes may suggest lead interference with lipid removal from these cells through impairment of ATP-dependent fatty acids [39].

\section{Conclusion}

The present study supports that lead induces hepatotoxic effects which are manifested as hepatocyte inflammation, hepatic damage as well as loss of hepatic reticular fibre. This is possibly due to oxidative stress induced following lead exposure. Moringa oleifera leaf extract has an appreciable ability to prevent hepatotoxicity caused by lead, possibly via its chemical constituents which has hepatoprotective properties.

\section{References}

[1] Karrari, P., Mehrpour, O. and Abdollahi, M. (2012) A Systematic Review on Status of Lead Pollution and Toxicity in Iran; Guidance for Preventive Measures. DARU Journal of Pharmaceutical Sciences, 20, 2. http://dx.doi.org/10.1186/1560-8115-20-2

[2] Nemsadze, T., Sanikidze, L., Ratiani, L., Gabunia, T. and Sharashenidze, T. (2009) Mechanisms of Lead-Induced Poisoning. Georgian Medical News, 172-173, 92-96.

[3] Adhikari, N., Sinha, N. and Narayan, R. (2001) Lead-Induced Cell Death in Testes of Young Rats. Journal of Applied Toxicology, 21, 275-277. http://dx.doi.org/10.1002/jat.754 
[4] Clayton, C.A., Pellizzari, E.D. and Quackenboss, J.J. (2002) National Human Exposure Assessment Survey: Analysis of Exposure Pathways and Routes for Arsenic and Lead in EPA Region 5. Journal of Exposure Analysis and Environmental Epidemiology, 12, 29-43. http://dx.doi.org/10.1038/sj.jea.7500198

[5] Skerfving, S. and Bergdahl, I.A. (2007) Chapter 31: Lead. In: Nordberg, G.F., Fowler, B.A., Norberg, M. and Friberg, L.T., Eds., Handbook on the Toxicology of Metals, 3rd Edition, Academic Press, Amesterdam, 599-643.

[6] Valko, M., Morris, H. and Cronin, M.T. (2005) Metals, Toxicity and Oxidative Stress. Current Medicinal Chemistry, 12, 1161-1208. http://dx.doi.org/10.2174/0929867053764635

[7] Sivaprasad, R., Nagaraj, M. and Varalakshmi, P. (2004) Combined Efficacies of Lipoic Acid and 2, 3-Dimercaptosuccinic Acid against Lead-Induced Lipid Peroxidation in Rat Liver. Journal of Nutritional Biochemistry, 15, 18-23. http://dx.doi.org/10.1016/j.jnutbio.2003.09.001

[8] Meyer, S.A. and Kulkarni, A.P. (2001) Hepatotoxicity. In: Hodgson, E. and Smart, R.C., Eds., Introduction to Biochemical Toxicology, 3rd Edition, John Wiley and Sons, New York, 487.

[9] Wolf, P.L. (1999) Biochemical Diagnosis of Liver Disease. Indian Journal of Clinical Biochemistry, 14, 59-64. http://dx.doi.org/10.1007/BF02869152

[10] Buraimoh, A.A., Bako, I.G. and Ibrahim, F.B. (2011) Hepatoprotective Effect of Ethanolic Leaves Extract of Moringa oleifera on the Histology of Paracetamol Induced Liver Damage in Wistar Rat. International Journal of Animal and Veterinary Advances, 3, 10-13.

[11] Ozbek, H., Ugras, S., Bayram, I., Uygan, I., Erdogan, E., Ozturk, A. and Huyut, Z. (2004) Hepatoprotective Effect of Foeniculum vulgare Essential Oil: A Carbon-Tetrachloride Induced Liver Fibrosis Model in Rats. Scandinavian Journal of Laboratory Animal Science, 31, 9-17.

[12] Okuda, T., Baes, A., Nishijima, W. and Okada, M. (2001) Coagulation Mechanism of Salt Solution-Extracted Active Component in Moringa oleifera Seeds. Water Research, 35, 830-834. http://dx.doi.org/10.1016/S0043-1354(00)00296-7

[13] Mughal, M.H., Ali, P.S. and Iqbal, M. (1999) Improvement of Drumstick (Moringa pterygosperma Gaertn): A Unique Source of Food and Medicine through Tissue Culture. Hamdard Medicus, 42, 37-42.

[14] Fuglie, L.J. (1999) The Miracle Tree: Moringa oleifera: Natural Nutrition for the Tropics. Church World Service, Dakar, 68.

[15] Pamok, S., Saenphet, S., Vinitketkumnuem, U. and Saenphet, K. (2012) Anti-Proliferation Effect of Moringa oleifera and Psenderanthera palatiferum Extracts on the Colon Cancer Cell. Journal of Medicinal Plants Research, 6, 139-145.

[16] Ghasi, S., Nwobodo, E. and Ofili, J.O. (2000) Hypocholesterolemic Effects of Crude Extract of Leaf of Moringa oleifera Lam in High-Fat Diet Fed Wistar Rats. Journal of Ethnopharmacology, 69, 21-25. http://dx.doi.org/10.1016/S0378-8741(99)00106-3

[17] Tahiliani, P. and Kar, A. (2000) Role of Moringa oleifera Leaf Extract in the Regulation of Thyroid Hormone Status in Adult Male and Female Rats. Pharmacological Research, 41, 319-323. http://dx.doi.org/10.1006/phrs.1999.0587

[18] Makonnen, E., Hunde, A. and Damecha, G. (1997) Hypoglycaemic Effect of Moringa stenopetala Aqueous Extract in Rabbits. Phytotherapy Resources, 11, 147-148. http://dx.doi.org/10.1002/(SICI)1099-1573(199703)11:2<147::AID-PTR41>3.0.CO;2-V

[19] Murakami, A., Kitazono, Y., Jiwajinda, S., Koshimizu, K. and Ohigashi, H. (1998) Niaziminin, a Thiocarbamate from the Leaves of Moringa oleifera, Holds a Strict Structural Requirement for Inhibition of Tumor-Promoter-Induced Epstein-Barr Virus Activation. Planta Medica, 64, 319-323. http://dx.doi.org/10.1055/s-2006-957442

[20] Faizi, S., Siddiqui, B.S., Saleem, R.K., Aftab, F., Shaheen, A. and Gilani, U.H. (1998) Hypotensive Constituents from the Pods of Moringa oleifera. Planta Medica, 64, 225-228. http://dx.doi.org/10.1055/s-2006-957414

[21] Trease, G.E. and Evans, M.D. (1989) A Textbook of Pharmacognosy. 13th Edition, Braillier, Tindal and Caussel, London.

[22] Sinha, A.K. (1972) Colorimetric Assay of Catalase. Analytical Biochemistry, 47, 389-394. http://dx.doi.org/10.1016/0003-2697(72)90132-7

[23] Drury, R.A. and Wallington, E.A. (1980) Carleton’s Histological Technique. 5th Edition, Oxford University Press, New York.

[24] Goyer, R.A. (1996) Results of Lead Research: Prenatal Exposure and Neurological Consequences. Environmental Health Perspectives, 104, 1050-1054. http://dx.doi.org/10.1289/ehp.961041050

[25] Chen, K.A., Golemboski, K.A., Sanders, F.S. and Dietert, R.R. (1999) Persistent Effect of in Uteromeso-2,3-dimercaptosuccinic Acid (DMSA) on Immune Function and Lead-Induced Immunotoxicity. Toxicology, 132, 67-79. http://dx.doi.org/10.1016/S0300-483X(98)00139-5 
[26] Adaramoye, O.A., Osaimoje, D.O., Akinsanya, A.M., Nneji, C.M., Fafunso, M.A. and Ademowo, O.G. (2008) Changes in Antioxidant Status and Biochemical Indices after Acute Administration of Artemether, Artemether-Lumefantrine and Halofantrine in Rats. Basic and Clinical Pharmacology and Toxicology, 102, 412-418. http://dx.doi.org/10.1111/j.1742-7843.2008.00211.x

[27] Adanaylo, V.N. and Oteiza, P.I. (1999) Lead Intoxication: Antioxidant Defenses and Oxidative Damage in Rat Brain. Toxicology, 135, 77-85. http://dx.doi.org/10.1016/S0300-483X(99)00051-7

[28] Yiin, S.J. and Lin, T.H. (1995) Lead-Catalyzed Peroxidation of Essential Unsaturated Fatty Acid. Biological Trace Element Research, 50, 167-172. http://dx.doi.org/10.1007/BF02789419

[29] Akilavalli, N., Radhika, J. and Brindha, P. (2011) Hepatoprotective Activity of Ocimum sanctum Linn. against Lead Induced Toxicity in Albino Rats. Asian Journal of Pharmaceutical and Clinical Research, 4, 84-87.

[30] Sharma, A., Sharma, V. and Kansal, L. (2009) Therapeutic Effects of Allium sativum on Lead-Induced Biochemical Changes in Soft Tissues of Swiss Albino Mice. Pharmacognosy Magazine, 5, 364-371. http://dx.doi.org/10.4103/0973-1296.58568

[31] Saalu, L.C., Ogunlade, B., Ajayi, G.O., Oyewopo, A.O., Akunna, G.G. and Ogunmodede, O.S. (2012) The HepatoProtective Potentials of Moringa oleifera Leaf Extract on Alcohol-Induced Hepato-Toxicity in Wistar Rat. American Journal of Biotechnology and Molecular Sciences, 2, 6-14. http://dx.doi.org/10.5251/ajbms.2012.2.1.6.14

[32] Ercal, N., Gurer-Orhan, H. and Aykin-Burns, N. (2001) Toxic Metals and Oxidative Stress. Part 1. Mechanisms Involved in Metal-Induced Oxidative Damage. Current Topics in Medicinal Chemistry, 1, 529-539. http://dx.doi.org/10.2174/1568026013394831

[33] Patra, R.C., Swarup, D. and Diwivedi, S.K. (2001) Antioxidant Effects of $\alpha$-Tocopherol, Ascorbic Acid and L-Methionine on Lead Induced Oxidative Stress to the Liver, Kidney and Brain in Rats. Journal of Toxicology, 162, 81-88. http://dx.doi.org/10.1016/S0300-483X(01)00345-6

[34] Cotran, R.S., Kumar, V., Fausto, N., Nelso, F., Robbins, S.L. and Abbas, A.K. (2005) Robbins and Cotran Pathologic Basis of Disease. 7th Edition, Elsevier Saunders, Philadelphia, 878.

[35] Ross, M.H., Kaye, G. and Paulina, W. (2006) Histology: A Text and Atlas. 5th Edition, Lippincott Williams \& Wilkins, Baltimore.

[36] Saud, A.A., Badr, A.A., Doaa, M.E. and Mohamed, A.D. (2012) Effect of Corn Oil, Flaxseed Oil and Black Seed Oil on Lead Acetate-Induced Hepatic Tissue Damage: A Histological Study. Journal of Medicinal Plants Research, 6, 4128-4134.

[37] Abdou, H. and Newairy, A. (2006) Hepatic and Reproductive Toxicity of Lead in Female Rats and Attenuation by Flaxseed Lignans. Journal of Medicinal Plants Research, 27, 295-302.

[38] Shatha, M.H. (2011) Effect of Lead Toxicity on Liver of Male Albino Mice Ultrastructural Study. Kufa Medical Journal, 14, 214-220.

[39] Piasek, M., Kostial, K. and Bunarevic, A. (1989) The Effect of Lead Exposure on Pathohistological Changes in the Liver and Kidney in Relation to Age in Rats. Archives of Industrial Hygiene and Toxicology, 40, 15-21. 